\title{
Impaired protamination and sperm DNA damage in a Nellore bull with high percentages of morphological sperm defects in comparison to normospermic bulls
}

\author{
[Deficiências de protaminação e danos de DNA no sêmen de um touro Nelore com elevada porcentagem de \\ patologias espermáticas em comparação a touros normospérmicos] \\ J.T. Carreira ${ }^{1}$, J.T. Trevizan ${ }^{2}$, B.H. Kipper ${ }^{2}$, S.H.V. Perri ${ }^{2}$, I.R. Carvalho ${ }^{2}$, \\ L.H. Rodrigues ${ }^{3}$, C. Silva ${ }^{4}$, M.B. Koivisto ${ }^{2 *}$ \\ ${ }^{1}$ Centro Universitário de Rio Preto - UNIRP, SP \\ ${ }^{2}$ Universidade Estadual Paulista - Faculdade de Medicina Veterinária - Unesp - Araçatuba, SP \\ ${ }^{3}$ Self-Employed Veterinarian - Sertãozinho, SP \\ ${ }^{4}$ CRVLagoa, Sertãozinho, SP
}

\begin{abstract}
The routine semen evaluation assessing sperm concentration, motility and morphology, does not identify subtle defects in sperm chromatin architecture. Bulls appear to have stable chromatin, with low levels of DNA fragmentation. However, the nature of fragmentation and its impact on fertility remain unclear and there are no detailed reports characterizing the DNA organization and damage in this species. The intensive genetic selection, the use of artificial insemination and in vitro embryo production associated to the cryopreservation process can contribute to the chromatin damage and highlights the importance of sperm DNA integrity for the success of these technologies. Frozen-thawed semen samples from three ejaculates from a Nellore bull showed high levels of morphological sperm abnormalities $(55.8 \pm 5.1 \%)$, and were selected for complementary tests. Damage of acrosomal $(76.9 \pm 8.9 \%)$ and plasma membranes $(75.7 \pm 9.3 \%)$ as well as sperm DNA strand breaks $(13.8 \pm 9.5 \%)$ and protamination deficiency $(3.7 \pm 0.6 \%)$ were significantly higher compared to the values measured in the semen of five Nellore bulls with normospermia $(24.3 \pm 3.3 \% ; 24.5 \pm 6.1 \% ; 0.6 \pm 0.5 \% ; 0.4 \pm 0.6 \%$ for acrosome, plasma membrane, DNA breaks and protamine deficiency, respectively) $(\mathrm{P}<0.05)$. Motility and percentage of spermatozoa with low mitochondrial potential showed no differences between groups. This study shows how routine semen analyses (in this case morphology) may point to the length and complexity of sperm cell damage emphasizing the importance of sperm function testing.
\end{abstract}

Keywords: bovine, chromatin integrity, protamine, sperm morphology

\section{RESUMO}

O exame de rotina de sêmen, o qual avalia a concentração de espermatozoides, a motilidade e a morfologia, pode não identificar defeitos sutis na arquitetura da cromatina de espermatozoides. Os touros parecem ter cromatina estável com baixos níveis de fragmentação do DNA. No entanto, a natureza da fragmentação e o seu impacto sobre a fertilidade ainda não estão claros e não há relatos que caracterizam a organização do DNA e os danos nessa espécie com mais detalhes. A seleção genética intensiva e o uso da inseminação artificial e da produção in vitro de embriões, além do processo de criopreservação, podem contribuir para o dano da cromatina, e sabe-se a importância da integridade do DNA espermático para o sucesso dessas tecnologias. Amostras de sêmen de três ejaculados de um touro Nelore com altos níveis de alterações morfológicas $(55,8 \pm 5,1 \%)$ foram selecionadas para realização de exames complementares. Os danos de acrossoma $(76,9 \pm 8,9 \%)$ e das membranas plasmáticas $(75,7 \pm 9,3 \%)$, bem como quebras de fita de DNA de espermatozoides $(13,8 \pm 9,5)$ e deficiência de protamina $(3,7 \pm 0,6)$ foram significativamente maiores em comparação aos valores avaliados no sêmen

Recebido em 18 de julho de 2013

Aceito em 25 de novembro de 2014

* Autor para correspondência (corresponding author)

E-mail: koivisto@fmva.unesp.br 
de cinco touros Nelore com normospermia $(24,3 \pm 3,3 \% ; 24,5 \pm 6,1 \% ; 0,6 \pm 0,5 \% ; 0,4 \pm 0,6 \%$ para acrossoma, membrana plasmática, quebras de DNA e deficiência de protamina, respectivamente) $(p<0,05)$. Motilidade e porcentagem de espermatozoides com baixo potencial mitocondrial não diferiram estatisticamente. Essas avaliações mostram que análises de sêmen de rotina (neste caso, morfologia) podem apontar para a extensão e a complexidade dos danos na célula espermática, o que indica que a deficiência de protamina e os danos no DNA podem ocorrer simultaneamente a defeitos morfológicos. Tal ocorrência enfatiza a importância das análises de sêmen clássicas e dos testes complementares.

Palavras-chave: bovinos, integridade da cromatina, protamina, morfologia espermática

\section{INTRODUCTION}

Laboratory assays for the assessment of semen quality traditionally involve the evaluation of sperm concentration, motility and morphology (Gillan et al., 2005). However, to obtain fertilizing ability, spermatozoa must gain specific features, such as an intact cytoplasmic membrane and functional acrosoma as well as a high mitochondrial membrane potential (Celeghini et al., 2004). Chromatin integrity is another important factor since DNA fragmentation has been shown to impair fertility (Benchaib et al., 2003) and embryo development (Ahmadi and $\mathrm{Ng}, 1999$ ).

Sperm function consists in the safe transport of the haploid paternal genome to the egg containing the maternal genome. The subsequent fertilization leads to transmission of a new unique diploid genome to the next generation. To be successful on this journey, remarkable arrangements need to be made during the postmeiotic stages of spermatogenesis. Haploid spermatids undergo extensive morphological changes, including a striking reorganization and compaction of their chromatin (Rahtke et al., 2014).

Sperm DNA is organized in a specific manner that keeps the nuclear chromatin compact, stable and protected (Agarwal and Said, 2003; Balhorn, 2011; Sharma and Agarwal, 2011). During spermatogenesis, sperm DNA interacts with protamines coiling sperm DNA into toroidal subunits, also known as doughnut loops. This unique packaging is essential for appropriate decondensation and reorganization of the paternal genome following fertilization. The retention of histones leads to a less compact chromatin and may influence the gene expression after fertilization (Gardiner-Garden et al., 1998).
Variation between bulls considering sperm protamine content has been described by fluorescent microscopy (Simões et al., 2009). Bulls exposed to a testicular heat insult through scrotal insulation showed decreased protamine content (Rahman et al., 2011). Oliveira et al. (2012) observed that bull fertility was associated to abnormal chromatin condensation characterized through excessive retention of sperm histones.

Spermatozoa DNA fragmentation may occur due to the attack of different endogenous or exogenous factors such as nucleases, free radicals, mutagens, handling during ART and other agents, especially if protamination of the DNA is defective (Sotolongo et al., 2000; Szczygiel and Ward, 2002). Protamines may be involved in the protection of genetic messages delivered by the spermatozoa (Mengual et al., 2003). Fortes et al (2014) found that protamination failure is related to DNA damage and lower testicular circumference in bulls. A clear relationship was found between sperm abnormalities classified as major sperm defects and poor DNA quality (Enciso et al., 2011), emphasizing the need for multiple evaluation of sperm parameters, including DNA integrity and protamination.

\section{CASE REPORT}

Frozen-thawed semen samples from three ejaculates of a 7-year old Nellore bull (Bull A) were evaluated by routine examination. Samples presented a high percentage of morphological defects (Blom, 1973) when compared to frozenthawed semen samples from five Nellore bulls (6.8 \pm 2.3 years - three ejaculates each) handled at the same insemination centre $\left(21^{\circ} 04^{\prime} 52^{\prime \prime} \mathrm{S}\right.$, $48^{\circ} 02^{\prime} 24^{\prime \prime} \mathrm{W}$, datum WGS84). All bulls were kept on native pasture (Cynodon plectostachyus) and fed a dietary supplementation. 
Immediately after thawing $\left(35^{\circ} \mathrm{C}\right.$ for $\left.20 \mathrm{sec}\right)$, the percentage of progressively motile sperm were determined by subjective estimation using phase contrast microscopy (200x). Sperm concentration $\left(\mathrm{x} 10^{6} / \mathrm{ml}\right)$ was determined under phase-contrast optics (200x) using a haemocytometer Neubauer chamber. For evaluation of sperm morphology sperm alterations were classified into major defects and minor defects Blom (1973) and a total of 200 cells (\%, DIC microscopy, oil immersion, 1000x, Olympus BX61) were examined per sample.

Motility and percentage of spermatozoa with intact acrosome (\%, DIC microscopy, oil immersion, 1000x, Olympus BX61) were evaluated after 3 hours of incubation at $37^{\circ} \mathrm{C}$ in a slow thermo-resistance test (STR). Simultaneous fluorescent microscopical evaluation (Olympus BX61, Tokyo, Japan) for plasma membrane integrity was performed using propidium iodide (PI, Sigma, St. Louis, MO, USA), fluoresceinconjugated Pisum sativum agglutinin (FITCPSA, Sigma, MO, USA) for acrosomal integrity and JC-1 (Sigma, St.Louis, MO, USA), for mitochondrial function.
Sperm protamination was analyzed by fluorescent microscope (Olympus BX61, Tokyo, Japan) with Chromomicin $\mathrm{A}_{3}$ staining $\left(\mathrm{CMA}_{3}\right.$ Sigma, St. Louis, MO, USA) (Simões et al., 2009) and chromatin integrity was evaluated using acridine orange (AO, Sigma, St. Louis, MO, USA) (Carreira et al., 2012). Mean values and standard deviations were calculated and were compared by Tukey test. Differences were considered statistically significant when $\mathrm{P}<0.05$.

\section{RESULTS}

The percentages of progressive motile spermatozoa before and after STR, as well as mitochondrial status, were statistically similar in all six bulls (Table 1). Bull A showed higher percentages of major morphological sperm defects (Table 2), sperm with deficient protamination and damaged chromatin, before and after STR, as well as lower percentages of sperm with intact plasma membrane and acrosomal membrane $(\mathrm{P}<0.05)$ compared with the reference group (Table 1).

Table 1. Semen traits (mean \pm SD) in Bull A and reference group $(\mathrm{n}=5)$

\begin{tabular}{lll}
\hline & \multicolumn{1}{c}{ Variable } & \multicolumn{1}{c}{ Reference group } \\
\hline Motile sperm (\%) Oh & $45.0 \pm 8.7 \mathrm{a}$ & $45.4 \pm 5.7 \mathrm{a}$ \\
Motile sperm (\%) 3h & $30.0 \pm 5.0 \mathrm{a}$ & $35.1 \pm 2.0 \mathrm{a}$ \\
Total sperm defects & $55.8 \pm 5.1 \mathrm{a}$ & $9.9 \pm 2.8 \mathrm{~b}$ \\
Damaged acrosome (\%)* & $76.9 \pm 8.9 \mathrm{a}$ & $24.3 \pm 3.3 \mathrm{~b}$ \\
Damaged plasma membrane (\%)* & $75.7 \pm 9.3 \mathrm{a}$ & $24.5 \pm 6.1 \mathrm{~b}$ \\
Low mitochondrial potential (\%)* & $85.0 \pm 2.18 \mathrm{a}$ & $83.1 \pm 13.3 \mathrm{a}$ \\
Deficient protamine (CMA3 \%) & $3.7 \pm 0.6 \mathrm{a}$ & $0.4 \pm 0.6 \mathrm{~b}$ \\
Damaged chromatin (AO \%) 0h & $13.8 \pm 9.5 \mathrm{a}$ & $0.6 \pm 0.5 \mathrm{~b}$ \\
Damaged chromatin (AO \%) 3h & $19.8 \pm 9.5 \mathrm{a}$ & $0.6 \pm 0.5 \mathrm{~b}$ \\
\hline
\end{tabular}

Means with different superscripts in the same line differ significantly. (Tukey test $<0.05$ ). CMA3 - Chromomicin $\mathrm{A}_{3}$; $\mathrm{AO}$ - acridine orange; $0 \mathrm{~h}$ - before incubation; $3 \mathrm{~h}-$ after $3 \mathrm{~h}$ incubation at $37^{\circ} \mathrm{C}$

*Simultaneous evaluation (0h) under fluorescence microscopy - FITC-PSA, PI and JC-1

Table 2. Main differences between morphologically abnormal sperm cells (means \pm SD) for Bull A and reference group $(n=5)$

\begin{tabular}{llll} 
Morphological abnormalities (\%) & Bull A & Reference group \\
\hline Major defects & Proximal cytoplasmic droplet & $17.7 \pm 3.5$ & $0.5 \pm 0.3$ \\
\cline { 2 - 3 } & Teratoid form & $7.0 \pm 1.5$ & $0.3 \pm 0.3$ \\
\cline { 2 - 3 } & $\begin{array}{l}\text { Membrane defect (rolled head-nuclear } \\
\text { crest-giant syndrome) }\end{array}$ & $10.3 \pm 1.8$ & $0.4 \pm 0.1$ \\
\cline { 2 - 3 } & $\begin{array}{l}\text { Midpiece defect (corkscrew, } \\
\text { pseudodroplet, etc.) }\end{array}$ & $6.0 \pm 1.3$ & $1.0 \pm 1.0$ \\
\cline { 2 - 3 } & Dag defects & $6.5 \pm 1.8$ & $0.9 \pm 1.0$ \\
\hline Minor Defects & Detached heads & $6.8 \pm 2.8$ & $2.0 \pm 2.3$ \\
\hline
\end{tabular}




\section{DISCUSSION}

Simultaneous evaluation of sperm attributes should provide a better estimate of the percentage of sperm in the semen sample that could actually fertilize an oocyte (Graham, 2001). Even though laboratory assay results do not allow accurate evaluation of the fertilizing potential of a semen sample, these assays are important to enable elimination of poor quality samples (Graham and Mocé, 2005). However, another study showed that semen analysis based only on Brazilian College of Animal Reproduction criteria without any additional functional tests were sufficient to guarantee the achievement of satisfactory pregnancy rates (Emerick, 2007). Nevertheless, results between Bull $\mathrm{A}$ and the reference group highlight the fact that more than one injure or defect can be associated to a sperm cell and in some cases semen quality assessment will require complementary tests.

Bull A showed high levels of sperm with morphological defects, especially major defects such as proximal cytoplasmic droplets, teratoid spermatozoa, rolled head-nuclear crest-giant syndrome, midpiece and "Dag" defects. According to Enciso et al. (2011) major morphological sperm abnormalities are associated with DNA damage and some specific alterations, such as proximal cytoplasmic droplets, which are only recognized in DNA damaged spermatozoa.

The reorganization of sperm chromatin is initiated during the post-meiotic phase of spermatocytogenesis (Sassone-Corsi, 2002). The replacement of histone proteins to testis specific histone variants occurs during spermatogenesis (Churikov et al., 2004).

At spermiogenesis, histones are lost, replaced by transitional proteins and then ultimately replaced by protamines (Lee and Cho, 1999; Kierszenbaum, 2001; Zhao et al., 2004). The complete replacement of histones by protamines and final compaction of chromatin is observed in mature spermatozoa in the cauda epididymis and therefore in the ejaculated spermatozoa.

Hence, during spermatogenesis and sperm maturation DNA replication and packaging take place, any disturbance of this process can result in the production of morphologically abnormal spermatozoa, some of which may present defective chromatin structure (Enciso et al., 2011).

Spermatozoa with abnormal morphology may fail at different steps of fertilization depending on the nature of abnormality, and sperm defects may indicate accompanying functional deficiencies, such as abnormal spermatogenesis affecting the structure and function of the entire sperm population (Thundathil, 2001).

Bull A showed an increased percentage of sperm with damaged chromatin and deficient protamine. Fortes et al (2014) showed that sperm protamine content and sperm DNA damage are closely associated, since protamine deficiency is likely to be one of the contributing factors of DNA instability and damage.

Considering that DNA packaging and final steps of protamine compacting in spermatozoa occur during epididymal transit (Dadoune, 2003) in close temporal relationship with the removal of cytoplasmic droplets, it can be assumed that epididymal dysfunction may impair various aspects of the sperm function. Low rates of protamine alterations do not seem to affect fertility in Nellore bulls (Simões et al., 2009) but at the present there are no reference values. In this study fluorochrome CMA3 was used as an indicator for protamine deficiency (Figure 1), it forms an ion co-ordinated dimer, which binds to this minor groove of the GC-rich DNA sequence mediated by a single divalent metal ion, such as Mg2+ (Bianchi et al., 1996; Hou et al., 2004; Simoes et al., 2009). In mature spermatozoa, where DNA is compacted and stabilized by protamines, the GC-rich minor grooves are masked by the argenine-rich sequence of the protamines, and therefore they are inaccessible to CMA3 binding. Because CMA3 is unable to bind when protamines are present, the differences in fluorescence intensity are used to detect deficiency (Fatehi et al., 2006; Tavalaee et al., 2010). The shortage of published papers using CMA3 staining in bovines complicates the interpretation of results, which were always markedly below the values reported in other species (Carreira et al., 2008; Simões et al., 2009; Carreira et al., 2010). It is possible that protamine deficiency in bovine may be underestimated, nevertheless this is the first reported bull with expressive levels of defective protamination. 


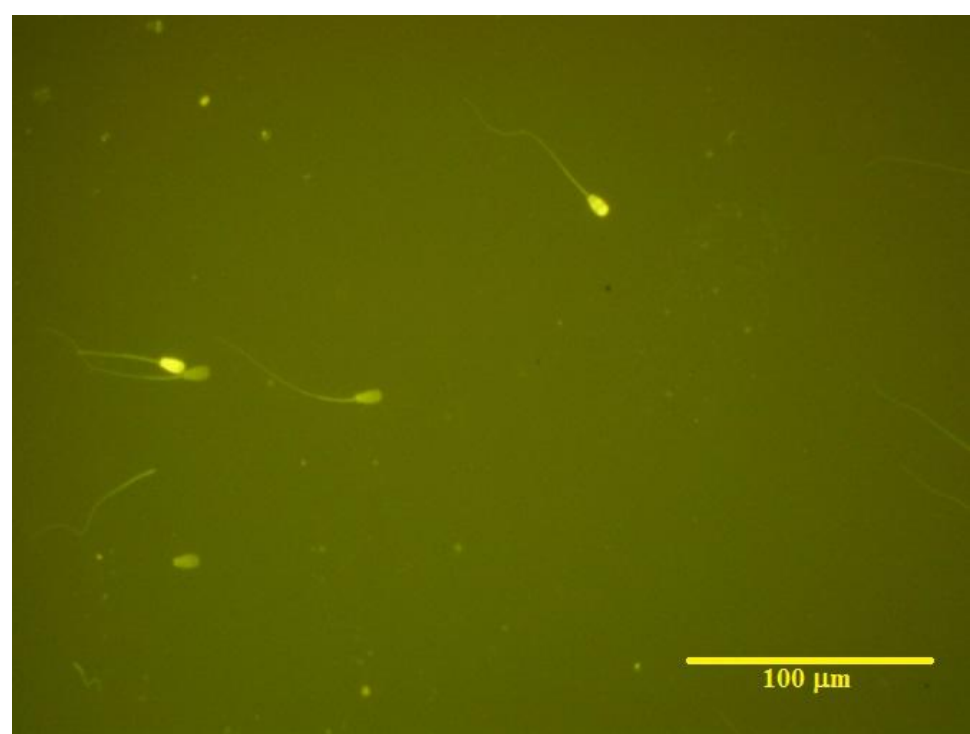

Figure 1. Illustrative bovine sperm cells stained with CMA3. Presence of two positive sperm cells showing protamine deficiency (higher fluorescence) (Olympus BX61, fluorescence microscopy, 400x).

\section{CONCLUSION}

In the present case, increased protamine deficiency and DNA damage is probably the consequence of disturbed spermatogenesis or sperm maturation resulting in high levels of sperm with major morphological defects and chromatin damage. The findings reiterate the importance of classical sperm classification as well as the complementary analyses of semen samples. Depth researches are required to investigate the causal association of impaired spermatogenesis as well as deficient protamination, DNA damage and morphological defects.

\section{ACKNOWLEDGEMENTS}

Grant \#2006/03537-1 and Grant \#2010/07599-1, São Paulo Research Foundation (FAPESP).

\section{REFERENCES}

AGARWAL, A.; SAID, T.M. Role of sperm chromatin abnormalities and DNA damage in male infertility. Human Reprod. Update, v.9, p.331-345, 2003.

AHMADI, A.; NG, S.C. Fertilizing ability of DNA-damaged spermatozoa. J. Exp. Zool., v.284, p.696-704, 1999.
BALHORN, R. Sperm Chromatin: an overview. In: ZINI, A.; AGARWAL, A. Sperm Chromatin: Biological and Clinical Applications in Male Infertility and Assisted Reproduction. 1.ed., USA: Springer, 2011. Cap.1, p.3-18.

BENCHAIB, M.; BRAUN, V.; LORNAGE, J. et al. Sperm DNA fragmentation decreases pregnancy rate in an assisted reproductive technique. Human Reprod.. v.18, p.1023-1028, 2003.

BIANCHI, P.G.; MANICARDI, G.C.; URNER, F. Chromatin package: Relationship with sperm morphology, sperm-zona pellucida binding. Mol. Hum. Reprod., v.2, p.139-144, 1996.

BLOM, E. Ultrastructure of some characteristic sperm defects and a proposal for a new classification of the bull spermiogram. Nordisk Veterinaer Medicin., v.25, p.383-391, 1973.

CARREIRA, J.T.; MINGOTI, G.Z.; RODRIGUES, L.H. et al. Impact of proximal cytoplasmic droplets on quality traits and in-vitro embryo production efficiency of cryopreserved bull spermatozoa. Acta Vet. Scand., v.54, p.1, 2012.

CARREIRA, J.T.; TREVIZAN, J.T.; CARVALHO, I.R. et al. DNA integrity and protamination of Bos taurus and Bos indicus Bulls - previous note. In: INTERNATIONAL SYMPOSIUM ON ANIMAL BIOLOGY OF REPRODUCTION, 3., 2010. Anais... Águas de São Pedro: CBRA. Animal Reproduction, v.7, 2010. 
CARREIRA, J.T.; KOIVISTO, M.B.; MINGOTI, G.Z. et al. The effect of high levels of proximal cytoplasmic droplets on sperm functional competence. In: INTERNATIONAL CONGRESS ON ANIMAL REPRODUCTION, 16., 2008, Budapest. Reprod. Domestic Anim., v.43. p.34-34, 2008.

CELEGHINI, E.C.C.; ARRUDA, R.P.; ANDRADE, A.F.C. et al. Simultaneous evaluation of the plasmatic, acrosomal and mitochondrial membranes in equine spermatozoa. In: INTERNATIONAL CONGRESS ON ANIMAL REPRODUCTION, 15., 2004. Proceedings... Porto Seguro: Elsevier 2004. p.511.

CHURIKOV, D.; ZALENSKAYA, I.A.; ZALENSKY, A.O. Male germline-specific histones in mouse and man. Cytogenet Genome Res., v.105, p.203-214, 2004.

DADOUNE, J.P. Expression of mammalian spermatozoa nucleoproteins. Microsc. Res. Techniq., v.61, p.56-75, 2003.

EMERICK M.C.; MONTENEGRO, K.B.M.; DEGRAVE, W. Novas tecnologias na genética humana: avanços $e$ impactos para a saúdelorganizadores. Rio de Janeiro: GESTECNit, 2007. 252p.

ENCISO, M.; CISALE, H.; JOHNSTON, S.D. Major morphological abnormalities in the Bull are related to sperm DNA damage. Theriogenology, v.76, p.23-32, 2011.

FATEHI, A.N.; BEVERS, M.M.; SCHOEVERS, E. et al. DNA damage in bovine sperm does not block fertilization and early embryonic development but induces apoptosis after the first cleavages. J. Androl., v.27, p.176-188, 2006.

FORTES, M.R.S.; SATAKE, N.; CORBET, D.H.; CORBET, N.J. Sperm protamine deficiency correlates with sperm DNA damage in Bos indicus bulls. Andrology, v.2, p.370-378, 2014.

GARDINER-GARDEN，M.; BALLESTEROS, M.; GORDON, M.; TAM, P. Histone- and Protamine-DNA Association: Conservation of Different Patterns within the $\beta$-Globin Domain in Human Sperm. Mol. Cell Biol., v.18, p.33503356, 1998 .
GILLAN, L.; EVANS, G.; MAXWELL, W.M.C. Flow cytometric evaluation of sperm parameters in relation to fertility potential. Theriogenology, v.63, p.445-457, 2005.

GRAHAM, J.K. Assessment of sperm quality: a flow cytometric approach. Anim. Reprod. Sci., v.68, p.239-247, 2001.

GRAHAM, J.K.; MOCÉ, E. Fertility evaluation of frozen/thawed semen. Theriogenology, v.64, p.492-504, 2005.

HOU, M.H.; ROBINSON, H.; GAO, Y.G.; WANG, A.H.J. Crystal structure of the [Mg2+(chromomycin A3)2]-d(TTGGCCAA)2 complex reveals GGCC binding specificity of the drug dimer chelated by a metal ion. Nucleic Acids Res., v.32, p.2214-2222, 2004.

KIERSZENBAUM, A.L. Transition nuclear proteins during spermiogenesis: unrepaired DNA breaks not allowed. Mol. Reprod. Dev., v.58, p.357-358, 2001.

LEE, C.H.; CHO, Y.H. Aspects of mammalian spermatogenesis: electrophoretical analysis of protamines in mammalian species. Mol. Cells, v.9, p.556-559, 1999.

MENGUAL, L.; BALLESCA, J.L.; ASCASO, C.; OLIVA, R. Marked differences in protamine content and $\mathrm{P} 1 / \mathrm{P} 2$ ratios in sperm cells from Percoll fractions between patients and controls. J. Androl., v.24, p.438-447, 2003.

OLIVEIRA, L.Z.; ARRUDA, R.P.; ANDRADE, A.F.C. et al. Effect of sequence of insemination after simultaneous thawing of multiple semen straws on conception rate to timed AI in suckled multiparous Nelore cows. Theriogenology, v.78, p.1800-1813, 2012.

RAHMAN, M.B.; KAMAL, M.M.; RIJSSELAERE, $\mathrm{T}$. et al. Altered chromatin conformation in bovine spermatozoa perturbs dynamic DNA methylation in the male pronucleus after fertilization in vitro. Reprod. Fertil. Dev., v.25, p. 150,2013

RATHKE, C.; BAARENDS, W.M.; AWE, S.; RENKAWITZ-POHL, R. Chromatin dynamics during spermiogenesis, Biochimica et Biophysica Acta (BBA) - Gene Regulatory Mechanisms. v.1839, p.155-168, 2014. 
SASSONE-CORSI, P. Unique Chromatin Remodeling and Transcriptional Regulation in Spermatogenesis. Science. v.21, p.2176-2178, 2002.

SHARMA, R.; AGARWAL, A. Spermatogenesis: an overview. In: ZINI, A.; AGARWAL, A. Sperm Chromatin: Biological and Clinical Applications in Male Infertility and Assisted Reproduction. 1.ed., USA: Springer, 2011. Cap.2, p.19-44.

SIMÕES, R.; FEITOSA, W.B.; MENDES, C.M. et al. Use of chromomycin A3 staining in bovine sperm cells for detection of protamine deficiency. Biotech. Histochem., v.84, p.73-79, 2009.

SOTOLONGO, B.; WARD, W.S. DNA Loop Domain Organization: The Three Dimensional Genomic Code . J. Cell Biochem., v.35, Suppl., p.23-26, 2000.
SZCZYGIEL, M.A.; WARD, W.S. The combination of dithiothreitol and detergent treatment of spermatozoa causes paternal chromosomal damage. Biol. Reprod., v.67, p.1532-1537, 2002.

TAVALAEE, M.; KIANI, A.; ARBABIAN, M.; DEEMEH, M.R.; ESFAHANI, MOHAMMAD, H.N. Flow Cytometry: A New Approach for Indirect Assessment of Sperm Protamine Deficiency International. J. Fert. Steril., v.3, p.177-184, 2010.

THUNDATHIL, J.C. In vitro fertilizing characteristics of bovine sperm with abnormal morphology. [PhD thesis]. University of Saskatchewan. Saskatoon-Saskatchewan, Canada, 2001.

ZHAO, M.; SHIRLEY, C.R.; MOUNSEY, S.; MEISTRICH, M.L. Nucleoprotein transitions during spermiogenesis in mice with transition nuclear protein Tnp1 and Tnp2 mutations. Biol. Reprod., v.71, p.1016-1025, 2004. 